\title{
ODGOVORNOST ZA ŠTETU ZAKONSKOG REVIZORA I OBVEZA OSIGURANJA OD ODGOVORNOSTI ZA ŠTETU
}

\author{
Prof. dr. sc. Dionis Jurić* \\ Izv. prof. dr. sc. Loris Belanić**
}

\author{
UDK: $347.426 .6: 368.87$ \\ 347.72:368.87 \\ https://doi.org/10.30925/zpfsr.39.4.13 \\ Ur.: 31. kolovoza 2018. \\ Pr.: 5. listopada 2018. \\ Pregledni znanstveni rad
}

\section{Sažetak}

Odgovornost zakonskih revizora za štetu počinjenu subjektu revizije i trećim osobama pri obavljanju revizorskih usluga jedno je od otvorenih pitanja koja nisu usklađena odgovarajućim direktivama Europske unije. Ono je uređeno nacionalnim propisima država članica EU-a koji upućuju na primjenu općih ili posebnih odredbi o odgovornosti za štetu ili kombiniranu primjenu tih odredbi. Zakon o reviziji iz 2017. godine ne sadrži posebne odredbe o odgovornosti zakonskih revizora za štetu, već se primjenjuju opće odredbe o odgovornosti za štetu iz Zakona o obveznim odnosima. Zakon o reviziji predviđa obvezu zakonskog revizora sklopiti ugovor o osiguranju od odgovornosti za štetu koja može nastati subjektu revizije i trećim osobama te propisuje najmanju svotu pokrića. Također uvodi opće zahtjeve za obavljanje zakonskih revizija u svim obveznicima zakonske revizije te posebne zahtjeve koji se primjenjuju na zakonske revizije u subjektima od javnog interesa. Cilj je tih odredbi jačanje neovisnosti i objektivnosti zakonskih revizora u odnosu na subjekte revizije te osiguravanje njihova pravilnog i zakonitog rada.

Ključne riječi: zakonski revizor; odgovornost za štetu; osiguranje od odgovornosti; subjekti revizije; treće osobe.

\section{1. $U$ VOD}

Svrha je zakonske revizije provjera i ocjenjivanje godišnjih financijskih izvješća, godišnjih konsolidiranih financijskih izvješća i drugih financijskih izvješća

* Dr. sc. Dionis Jurić, redoviti profesor, Sveučilište u Rijeci, Pravni fakultet; djuric@pravri.hr.

** Dr. sc. Loris Belanić, izvanredni profesor, Sveučilište u Rijeci, Pravni fakultet; lorisb@pravri. $\mathrm{hr}$.

Ovaj je rad izrađen uz potporu Hrvatske zaklade za znanost, projekt br. 9366 "Pravni aspekti korporativnih akvizicija i restrukturiranje društava utemeljenih na znanju" i Sveučilišta u Rijeci, projekt br. 13.08.1.2.01 "Zaštita korisnika na hrvatskom i europskom tržištu financijskih usluga". 
te podataka i metoda korištenih pri njihovom sastavljanju od strane subjekata revizije. Na temelju toga, revizori daju neovisno stručno mišljenje o tomu prikazuju li financijska izvješća u svim bitnim odrednicama istinit i fer prikaz financijskog položaja i uspješnosti poslovanja te novčanih tokova u skladu s primjenjivim okvirom financijskog izvještavanja ili, ako je to primjenjivo, jesu li financijska izvješća u skladu s propisima. Izvješće o reviziji služi različitim korisnicima u subjektu revizije i izvan njega (organima subjekta revizije, njegovim članovima i vjerovnicima, s njime povezanim društvima, potencijalnim ulagateljima i kreditorima, javnosti i sl.). Oni se njime izvješćuju o točnosti sastavljenih financijskih izvješća i solventnosti subjekata revizije, o postojanju prijevarnih radnji, poštovanju pravnih obveza subjekata revizije te njihovu odgovornom ponašanju u odnosu na zaštitu okoliša i općedruštvena pitanja. ${ }^{1}$ Obveznici su zakonske revizije određeni čl. 20. Zakona o računovodstvu (dalje: ZRač). ${ }^{2}$ Zakonsku reviziju mogu obavljati samo revizorska društva.

Za točnost financijskih izvješća i solventnost subjekta revizije odgovaraju članovi njegovih upravnih i nadzornih organa. Revizor ima zadaću ocijeniti jesu li financijska izvješća izrađena u skladu sa zakonom i računovodstvenim standardima i prikazuju li istinitu i fer sliku financijske situacije poduzetnika, pri čemu konačni sud o izvješću revizora daje nadzorni organ poduzetnika. To proizlazi iz odredbi Zakona o trgovačkim društvima (dalje: ZTD) ${ }^{3}$ koje uređuju postupak utvrđivanja godišnjih financijskih izvješća u trgovačkim društvima. ${ }^{4}$

Korisnici izvješća o reviziji očekuju od zakonskog revizora utvrditi postojanje prijevarnih radnji ili povreda pravnih propisa koje mogu imati za posljedicu

1 European Commission, Green Paper of the Commission 1996, The Role, the Position and the Liability of the Statutory Auditors within the European Union, dostupno na: http://europa. eu.int/comm/internal_market/en/company/audit/docs/acten.pdf, 30. listopada 2003., str. 10.

2 Zakon o računovodstvu, Narodne novine, br. 78/15, 134/15, 120/16. To su: a) subjekti od javnog interesa te veliki i srednji poduzetnici koji nisu subjekti od javnog interesa, b) poduzetnici koji su vladajuća društva velikih i srednjih grupa ako nisu obveznici zakonske revizije sukladno točki a), c) dionička društva, komanditna društva i društva s ograničenom odgovornošću koja ispunjavaju posebno propisane uvjete, a nisu obveznici zakonske revizije sukladno točkama a) i b), d) poduzetnici koji su podnijeli zahtjev za uvrštavanje svojih vrijednosnih papira na uređeno tržište kapitala, a nisu obveznici zakonske revizije prema točkama a), b) i c) te e) poduzetnici koji su sudjelovali u poslovnim pripajanjima, spajanjima, odnosno podjelama kao preuzimatelji ili novoosnovana društva ako nisu obveznici revizije prema prethodnim točkama. Ostali poduzetnici na koje se primjenjuju odredbe ZRač-a mogu svojim osnivačkim (temeljnim) aktima ili odlukom svojih članova odrediti obvezu revizije godišnjih financijskih izvješća i/ ili godišnjih konsolidiranih financijskih izvješća (dragovoljna revizija). Pod poduzetnicima se podrazumijevaju trgovačka društva i trgovci pojedinci određeni ZTD-om.

3 Zakon o trgovačkim društvima, Narodne novine, br. 111/93, 34/99, 121/99, 52/00, 118/03, 107/07, 146/08, 137/09, 125/11, 152/11, 111/12, 68/13, 110/15.

4 Godišnja financijska izvješća i izvješće o stanju društva te prijedlog odluke o upotrebi dobiti sastavlja uprava, odnosno izvršni direktori dioničkog društva, a utvrđuju ih uprava i nadzorni odbor, odnosno izvršni direktori i upravni odbor društva (čl. 300.a-300.d ZTD). Iznimno to može činiti i glavna skupština društva (čl. 300.e ZTD). U društvu s ograničenom odgovornošću ta izvješća sastavlja uprava društva, a utvrđuje ih skupština društva (čl. 428. st. 2. i čl. 441. st. 1. t. 1. ZTD). Ako društvo ima nadzorni odbor, uprava izvješća mora dostaviti na pregled tom organu. 
netočnosti u financijskim izvješćima koja su predmet revizije. I ovdje je ponajprije uloga nadzornog organa subjekta revizije utvrditi moguća protuzakonita postupanja upravnog organa te obveza upravnog organa izgraditi sustav unutarnje revizije. Obveza je zakonskog revizora planirati i provoditi reviziju tako da se može razumno očekivati da će utvrditi nedostatke i nepravilnosti u financijskim izvješćima poduzetnika, bilo da su oni izazvani prijevarom, nenamjernim pogreškama ili povredama pravnih propisa. ${ }^{5}$ Neutvrđivanje prijevare ili povrede zakona osnova su za uspostavu odgovornosti zakonskog revizora prema subjektu revizije, ali i trećim osobama uz ispunjenje određenih dodatnih pretpostavki. ${ }^{6}$

\section{POSTUPAK IMENOVANJA ZAKONSKOG REVIZORA U SUBJEKTU REVIZIJE I SKLAPANJE UGOVORA O REVIZIJI S IMENOVANIM ZAKONSKIM REVIZOROM}

Glavna skupština, odnosno skupština subjekta revizije ima ovlast imenovanja zakonskog revizora. ${ }^{7}$ Prijedlog odluke za imenovanje zakonskog revizora sastavlja nadzorni, odnosno upravni odbor dioničkog društva. Oni daju i nalog imenovanom zakonskom revizoru za ispitivanje godišnjih financijskih izvješća društva i konsolidiranih godišnjih financijskih izvješća povezanih društava (čl. 263. st. 2. ZTD) ${ }^{8}$ Ako je subjekt revizije subjekt od javnog interesa imenovanje zakonskog revizora obavlja se u skladu s odredbama čl. 41. Zakona o reviziji (dalje: ZRev) ${ }^{9}$ i čl. 16. Uredbe o zakonskim revizijama u subjektima od javnog interesa iz 2014. godine (čl. 41. st. 4. ZRev). ${ }^{10} \mathrm{U}$ čl. 16. Uredbe iz 2014. godine uređuju se posebnosti

5 Green Paper of The Commission 1996, str. 13-16.

6 European Commission, A study on systems of civil liability of statutory auditors in the context of a Single Market for auditing services in the European Union, 15 January 2001, dostupno na: http://europa.eu.int/comm/internal_market/en/company/audit/docs/auditliability.pdf, 31 . listopada 2003., str. 44-46. i 123-125.

7 U dioničkom društvu tu ovlast ima glavna skupština, a odluku o tomu donose dioničari većinom danih glasova (obična većina), osim ako statutom nije određena neka veća većina ili se traži i ispunjavanje dodatnih pretpostavki (čl. 275. st. 1. t. 4. i čl. 290. ZTD). U društvu s ograničenom odgovornošću ovlast imenovanja zakonskog revizora imaju članovi društva, odnosno skupština društva (čl. 441. st. 1. t. 7. ZTD). Odluka o tomu također se donosi većinom danih glasova na skupštini, osim ako društvenim ugovorom nije određena neka veća većina ili se traži i ispunjavanje dodatnih pretpostavki. Ako odluku o imenovanju zakonskog revizora donose članovi društva u pisanom obliku izvan skupštine, ta se većina računa prema ukupnom broju glasova kojima rspolažu članovi društva (čl. 440. st. 2. ZTD).

8 Svaki dioničar može dati i protuprijedlog za imenovanje zakonskog revizora prije ili tijekom održavanja glavne skupštine (čl. 282. i 283. ZTD). U društvima s ograničenom odgovornošću prijedlog za imenovanje i nalog za rad daje nadzorni odbor, ako društvo ima taj organ te mu je ta ovlast dana društvenim ugovorom. Ako društvo nema taj organ, o tomu odlučuju članovi društva, odnosno skupština. U društvima s ograničenom odgovornošću koja nisu obveznici zakonske revizije, svaki član društva može predložiti reviziju posljednjih godišnjih financijskih izvješća, a ako članovi, odnosno skupština društva to odbije, zahtjev za imenovanjem revizora trgovačkom sudu mogu podnijeti manjinski članovi društva (čl. 450. ZTD).

9 Zakon o reviziji, Narodne novine, br. 127/17.

10 Tako se u čl. 3. t. 1. ZRač-a kao subjekti od javnog interesa određuju: a) poduzetnici koji su 
imenovanja zakonskih revizora u subjektima od javnog interesa koji moraju imati revizijski odbor. ${ }^{11} \mathrm{U}$ tomu slučaju revizijski odbor podnosi preporuku nadzornom, odnosno upravnom odboru subjekta revizije za imenovanje revizorskog društva (čl. 16. st. 2. Uredbe iz 2014. godine). Preporuka revizijskog odbora priprema se nakon provedbe javnog natječaja za odabir revizorskog društva od strane subjekta revizije, a za provedbu tog postupka odgovoran je revizijski odbor (čl. 16. st. 3. Uredbe iz 2014. godine). Prijedlog odluke nadzornog, odnosno upravnog odbora za imenovanje revizorskog društva koji je upućen na glavnu skupštinu, odnosno skupštinu subjekta revizije ili njegovim članovima mora sadržavati preporuku i opredjeljenje koje je donio revizijski odbor. Ako prijedlog odluke o imenovanju revizorskog društva odstupa od opredjeljenja revizijskog odbora, u prijedlogu se moraju navesti razlozi za odstupanje od preporuke revizijskog odbora (čl. 16. st. 5. Uredbe iz 2014. godine). ${ }^{12}$ Time se u postupak izbora i imenovanja zakonskog revizora uključuju i dioničari, odnosno članovi subjekta revizije.

Nakon imenovanja revizorskog društva subjekt revizije sklapa s njime ugovor o reviziji, kojim se uređuju njegova prava i obveze u svezi sa zakonskom revizijom. ${ }^{13}$ Revizorsko društvo mora obavijestiti Ministarstvo financija o prvom sklapanju ugovora o reviziji sa subjektom od javnog interesa u tekućoj poslovnoj godini (čl. 40. st. 1. i 2. ZRev). Ugovor se sklapa u pisanom obliku, a mora sadržavati iznos naknade za obavljanje zakonske revizije (čl. 40. st. 3. ZRev). Revizorsko društvo ne smije ugovorene revizorske usluge ustupati drugim revizorskim društvima (čl. 40. st. 4. ZRev). Time se osigurava da zakonsku reviziju u subjektu revizije provodi onaj zakonski revizor kojega je i imenovao subjekt revizije te koji ispunjava propisane uvjete. Ugovor o reviziji može se raskinuti u skladu s odredbama Zakona o obveznim odnosima (čl. 40. st. 5. ZRev).$^{14} \mathrm{U}$ slučaju raskida ugovora o reviziji revizorsko društvo mora o tomu obavijestiti Ministarstvo financija u roku od 15 dana od datuma raskida te detaljno obrazložiti razloge koji su doveli do raskida ugovora. Nakon primljene obavijesti Ministarstvo financija može odlučiti o provedbi postupka nadzora nad

osnovani u skladu s propisima RH i čiji su vrijednosni papiri uvršteni na uređeno tržište kapitala bilo koje države članice EU-a kako je određeno zakonom kojim se uređuje tržište kapitala, b) taksativno određene kreditne i financijske institucije te c) trgovačka društva te druge pravne osobe od strateškog interesa za RH i trgovačka društva od posebnog interesa, u kojima RH ima udjele manje od $50 \%$, sukladno odluci Vlade RH kojom se utvrđuje popis trgovačkih društava i drugih pravnih osoba od strateškog i posebnog interesa za RH, osim pravnih osoba koje vode poslovne knjige i sastavljaju financijska izvješća u skladu s propisima kojima se uređuje proračunsko računovodstvo ili računovodstvo neprofitnih organizacija (čl. 3. t. 1. ZRač).

11 Revizijski odbor koji može biti samostalno tijelo ili pomoćno tijelo nadzornog, odnosno upravnog odbora subjekta revizije (čl. 65. st. 1. ZRev).

12 U tom je slučaju revizorsko društvo koje preporučuje nadzorni, odnosno upravni odbor moralo sudjelovati u postupku javnog natječaja za odabir zakonskog revizora. To se ne primjenjuje ako ovlasti revizijskog odbora obavlja nadzorni, odnosno upravni odbor subjekta revizije.

13 U ime i za račun subjekta revizije taj ugovor sklapa uprava, odnosno izvršni direktori trgovačkog društva, odnosno zastupnici po zakonu toga subjekta.

14 Razlike u mišljenjima, koje se odnose na područja računovodstva i revizije, predstavnika subjekta revizije i revizorskog društva ne mogu biti opravdana osnova za raskid ugovora. Odredbe čl. 40. st. 1. do 5. ZRev-a na odgovarajući se način primjenjuju i na druge ugovore o obavljanju revizorskih usluga (čl. 40. st. 7. ZRev). 
revizorskim društvom (čl. 40. st. 6. ZRev) ${ }^{15}$

\section{ZAKONODAVNE AKTIVNOSTI TIJELA EUROPSKE UNIJE U PODRUČJU ZAKONSKE REVIZIJE}

Kvaliteta rada i neovisnost zakonskih revizora u odnosu na subjekte revizije osobito je postala aktualna u posljednja dva desetljeća. To je bilo uvjetovano velikim financijskim skandalima u američkim i europskim uvrštenim dioničkim društvima početkom ovog stoljeća, kao i krizom u financijskom sektoru tijekom razdoblja od 2007. do 2009. godine. Stoga se javila potreba za poduzimanjem odgovarajućih mjera tijela EU-a i uvođenja mehanizama za poboljšanje točnosti i pouzdanosti izvješća o reviziji te osiguravanje neovisnosti zakonskih revizora u odnosu na subjekte revizije. ${ }^{16}$

Stoga je 2006. godine donesena Direktiva 2006/43/EZ o zakonskim revizijama godišnjih financijskih izvješća i konsolidiranih financijskih izvješća, ${ }^{17}$ a 2005. godine Odluka Komisije 2005/909/EZ o uspostavljanju skupine stručnjaka za savjetovanje Komisije i olakšavanje suradnje između sustava javnog nadzora ovlaštenih revizora i revizorskih društava. ${ }^{18}$ Temeljni su ciljevi Europske komisije bili jačanje neovisnosti zakonskih revizora u odnosu na subjekte revizije, unaprjeđenje obavještavajuće vrijednosti izvješća o reviziji u odnosu na ulagatelje i druge dionike, olakšavanje prekograničnog pružanja usluga revizije, unaprjeđenje i poboljšavanje nadzora rada zakonskih revizora te promicanje usklađenosti i suradnje u području revizije s trećim državama. ${ }^{19}$ Cilj je Direktive iz 2006. godine bio usklađivanje nacionalnih propisa država članica EU-a koji uređuju materiju zakonske revizije. Rješenja Direktive pratila su rješenja iz prava SAD-a. ${ }^{20}$

Kriza u financijskom sektoru koja je započela 2007. godine ponovno je ukazala na nedostatke $u$ radu zakonskih revizora te točnosti i pouzdanosti njihovih izvješća o reviziji godišnjih i konsolidiranih financijskih izvješća kreditnih i financijskih institucija te uvrštenih dioničkih društava. U međuvremenu su se povećala očekivanja

15 ZRev u čl. 43. određuje obvezu imenovanja i sklapanja ugovora o reviziji s više revizorskih društava u slučaju zakonske revizije u određenim subjektima od javnog interesa. Time se dodatno osigurava neovisnost zakonskih revizora u obavljanju revizije te osigurava kvaliteta njezine provedbe $\mathrm{u}$ određenim subjektima od javnog interesa koje obilježava složenost poslovanja ili su od strateškog interesa za RH.

16 Jurić, D., Uloga revizora u dioničkom društvu, Zbornik Pravnog fakulteta Sveučilišta u Rijeci, vol. 25 , br. 1, 2004., str. 323-325 i 347-349.

17 Direktiva 2006/43/EZ Europskog parlamenta i Vijeća od 17. svibnja 2006. o zakonskim revizijama godišnjih financijskih izvještaja i konsolidiranih financijskih izvještaja, kojom se mijenjaju direktive Vijeća 78/660/EEZ i 83/349/EEZ i stavlja izvan snage Direktiva Vijeća 84/253/EEZ (tekst značajan za EPG), Službeni list EU, L 157, 9. lipnja 2006., str. 87-107.

18 Odluka Komisije od 14. prosinca 2005. o uspostavljanju skupine stručnjaka za savjetovanje Komisije i olakšavanje suradnje između sustava javnog nadzora ovlaštenih revizora i revizorskih društava (2005/909/EZ), Službeni list EU, L 329, 16. prosinca 2005., str. 38-39.

19 European Commission, Auditing of companies' financial statements, https://ec.europa.eu/ info/business-economy-euro/company-reporting-and-auditing/auditing-companies-financialstatements_en, 5. prosinca 2017., str. 1 .

Jurić, D., op. cit., str. 324-325. i 349-350. 
javnosti i ulagatelja u rad zakonskih revizora koja premašuju njihovu stvarnu ulogu. Konačno, uočena je koncentracija na tržištu revizorskih usluga, što onemogućava širi izbor zakonskih revizora subjektima revizije te otežava prekogranično pružanje usluga revizije na unutarnjem tržištu EU-a malim i srednjim revizorima i ulazak novih sudionika na to tržište. ${ }^{21}$

Zbog toga je Europski parlament i Vijeće EU-a 16. travnja 2016. godine donijelo Direktivu 2014/56/EU o izmjeni Direktive o zakonskim revizijama iz 2006. godine (dalje: Direktiva iz 2014. godine) ${ }^{22}$ te Uredbu br. 537/2014 o posebnim zahtjevima u svezi sa zakonskom revizijom subjekata od javnog interesa (dalje: Uredba) ${ }^{23} \mathrm{Cilj}$ je Direktive iz 2014. godine poboljšati kvalitetu zakonske revizije jačanjem neovisnosti revizora te njihove profesionalne skeptičnosti u odnosu na subjekte revizije i njihove organe, postaviti zakonodavni okvir za sve zakonske revizije te ojačati javni nadzor nad revizorskom djelatnošću i unaprijediti suradnju između nacionalnih nadležnih tijela u EU-u. Kada se radi o zakonskoj reviziji u subjektima od javnog interesa, Europska se komisija odlučila za donošenje Uredbe koja se neposredno primjenjuje na području svih država članica EU-a (čl. 44. Uredbe). Njome se dopunjuju odredbe Direktive iz 2014. godine kada se radi o zakonskoj reviziji u subjektima od javnog interesa.

Navedene se direktive i Uredba iz 2014. godine nisu detaljnije pozabavile pitanjem odgovornosti zakonskih revizora za štetu nastalu subjektima revizije i trećim osobama u slučaju njihova nepravilnog i nezakonitog rada. One su predvidjele samo preventivne mjere kojima je cilj osiguravanje neovisnosti i objektivnosti zakonskih revizora u odnosu na subjekte revizije te točnosti i pouzdanosti njihovih izvješća o reviziji. Europska je komisija provela istraživanje i izradila studiju o odgovornosti za štetu zakonskih revizora u nacionalnim pravnim poredcima država članica EU-a 2001., a koja je dopunjena 2006. godine. ${ }^{24}$ Navedeno je istraživanje pokazalo bitne razlike između država članica EU-a u uređivanju te materije. Države članice EU-a većinom kombiniraju primjenu općih pravila i posebnih pravila o odgovornosti za štetu zakonskih revizora. Sve države članice EU-a prihvaćaju postojanje odgovornosti

21 Republika Slovenija, Zakon o spremembah in dopolnitvah Zakona o revidiranju, EVA 20161611-0002, dostupno na: http://www.pisrs.si/Pis.web/pregledPredpisa?id=ZAKO7354, 18. prosinca 2017., str. 10.

22 Direktiva 2014/56/EU Europskog parlamenta i Vijeća od 16. travnja 2014. o izmjeni Direktive 2006/43/EZ o zakonskim revizijama godišnjih financijskih izvještaja i konsolidiranih financijskih izvještaja (tekst značajan za EPG), Službeni list EU, L 158, 27. svibnja 2014., str. 196-226.

23 Uredba (EU) br. 537/2014 Europskog parlamenta i Vijeća od 16. travnja 2014. o posebnim zahtjevima u vezi zakonske revizije subjekata od javnog interesa i stavljanju izvan snage Odluke Komisije 2005/909/EZ (tekst značajan za EGP), Službeni list EU, L 158, 27. svibnja 2014., str. 77-112.

24 European Commission, A study on systems of civil liability of statutory auditors in the context of a Single Market for auditing services in the European Union, 15 January 2001 i European Commission, Annex I to the Commission Staff Working Paper The legal systems of civil liability of statutory auditors in the European Union, Update of the study carried out on behalf of the Commission by Thieffry \& Associates in 2001, October 2006, dostupno na: http://ec.europa.eu/ internal_market/auditing/docs/liability/consultation_annex1_en.pdf, 3. srpnja 2018. 
za štetu zakonskih revizora prema subjektima revizije, pri čemu ta odgovornost počiva na ugovornom odnosu između zakonskog revizora i subjekta revizije (ugovorna odgovornost zakonskog revizora za štetu) ${ }^{25}$ Kada se radi o odgovornosti prema trećim osobama, koje nisu u ugovornom odnosu sa zakonskim revizorom (izvanugovorna odgovornost zakonskog revizora za štetu) ${ }^{26}$ nacionalna pravna pravila država članica EU-a ne uređuju jednoobrazno tu materiju. Prisutno je opće stajalište o potrebi uspostave te odgovornosti, budući da se zakonska revizija obavlja i u javnom interesu. Postavlja se pitanje može li svaka treća osoba, neovisno o tomu nalazi li se u pravnoj vezi s ugovornim stranama iz ugovora o reviziji (zakonski revizor i subjekt revizije), postaviti zahtjev za naknadu štete. Pritom se razlikuju one države članice EU-a koje dopuštaju svakoj trećoj osobi koja je pretrpjela štetu nesavjesnom djelatnošću zakonskog revizora podići tužbu za naknadu štete ${ }^{27}$ i one koje dopuštaju takve tužbe uz određena ograničenja. ${ }^{28}$

Uzimajući u obzir nalaze svojega istraživanja, Europska je komisija uočila problem nejedinstvenoga pristupa država članica EU-a u pravnom uređenju ograničenja iznosa do kojega zakonski revizori odgovaraju za štetu počinjenu subjektima revizije i trećim osobama. ${ }^{29}$ Nepostojanje takvog ograničenja može ugroziti poslovanje zakonskih revizora zbog potencijalno visokih tužbenih zahtjeva za naknadu štete, a i otežati sklapanje ugovora o osiguranju od odgovornosti za štetu s osiguravajućim

25 U svim državama članicama EU-a subjekt revizije može postaviti zahtjev za naknadu štete protiv zakonskog revizora. To u ime subjekta revizije čini njegova uprava, odnosno izvršni direktori te likvidatori. U većini njih ta odgovornost zakonskog revizora počiva na povredi njegovih ugovornih obveza, pri čemu je na subjektu revizije teret dokaza postojanje povrede ugovorne obveze zakonskog revizora u svezi s pruženim revizorskim uslugama. Vidi u: European Commission, Annex I to the Commission Staff Working Paper The legal systems of civil liability of statutory auditors in the European Union, Update of the study..., str. 2.

26 U tu kategoriju spadaju trgovačka društva koja su povezana sa subjektom revizije, pojedinačni dioničari, odnosno članovi subjekta revizije, njegovi vjerovnici i radnici, potencijalni ulagatelji i kreditori, javnost i sl.

27 U većini država članica EU-a treće osobe mogu ponijeti zahtjev za naknadu štete protiv zakonskog revizora, uz uvjet dokazivanja postojanja krivnje, štetne radnje, nastale štete te uzročne veze između štete i štetne radnje. Loc. cit.

28 Cipar, Irska, Malta i Ujedinjeno Kraljevstvo traže da treće osobe dokažu i postojanje dužne pozornosti zakonskog revizora prema njima (zakonski revizor je znao ili morao znati da će njegovo izvješće o reviziji ili njegov rad služiti tužitelju za određenu svrhu). U Austriji i Njemačkoj treće osobe mogu postaviti zahtjev za naknadu štete na temelju općih pravila o odgovornosti za štetu ili na temelju prešutnih ugovora te sklapanja ugovora sa zaštitnim učinkom prema trećim osobama. Vidi u ibid., str. 2-4, Mićović, M., Bukovac Puvača, M., Odgovornost za štetu prouzročenu trećim osobama obavljanjem zakonske revizije, Zbornik Pravnog fakulteta Sveučilišta u Rijeci, vol. 39, br. 1, 2018., str. 162-163.

29 Prema istraživanju iz 2006. godine Austrija, Belgija, Grčka, Njemačka i Slovenija predviđale su zakonsko ograničenje iznosa do kojega zakonski revizori odgovaraju za počinjenu štetu. Ta se ograničenja ne primjenjuju u slučaju prijevarnog postupanja ili postojanja namjere zakonskog revizora pri obavljanju revizorskih usluga. U manjem broju država članica EU-a to se ograničenje moglo predvidjeti ugovorom o reviziji. Vidi u European Commission, Annex I to the Commission Staff Working Paper The legal systems of civil liability of statutory auditors in the European Union, Update of the study..., str. 6 i 8. 
društvima. ${ }^{30}$ Stoga je Europska komisija 2008. godine donijela Preporuku br. 2008/473/ EZ o ograničenju građanskopravne odgovornosti samostalnih revizora i revizorskih društava. ${ }^{31}$ Odredbe se Preporuke odnose na odgovornost za štetu samostalnih revizora i revizorskih društava koja obavljaju zakonsku reviziju godišnjih i godišnjih konsolidiranih financijskih izvješća poduzetnika koji su registrirani u državi članici EU-a i čiji su vrijednosni papiri uvršteni na uređeno tržište kapitala države članice EU-a (t. 1. Preporuke). Europska komisija preporuča ograničenje odgovornosti za štetu zakonskih revizora koja može nastati u svezi s njihovim pružanjem revizorskih usluga subjektima revizije, pri čemu se to ograničenje ne primjenjuje pri namjernom kršenju njihovih dužnosti (t. 2. Preporuke). To ograničenje odgovornosti treba postojati u odnosu na subjekta revizije te treće osobe, kada ih nacionalni propisi države članice EU-a ovlašćuju na podnošenje zahtjeva za naknadu štete (t. 3. Preporuke). Pritom ograničenje odgovornosti ne smije onemogućiti pravično obeštećenje subjekta revizije ili treće osobe (t. 4. Preporuke). Preporuka ostavlja slobodu državama članicama EU-a izabrati jednu ili više ponuđenih metoda ograničenja te odgovornosti (t. 5. Preporuke). ${ }^{32}$

\section{ODGOVORNOST ZA ŠTETU ZAKONSKOG REVIZORA U HRVATSKOM PRAVU}

Zakon o reviziji iz 2017. godine ne sadrži posebne odredbe o odgovornosti za štetu zakonskoga revizora prema subjektu revizije i prema trećim osobama. Stoga se

30 Obveza sklapanja ugovora o osiguranju postojala je u 23 države članice EU-a 2006. godine. Vidi u ibid., str. 9.

31 Preporuka Komisije br. 2008/473/EZ o ograničenju građanskopravne odgovornosti samostalnih revizora i revizorskih društava od 5. lipnja 2008. godine (notificirano pod dokumentarnim brojem C(2008) 2274) (tekst značajan za EGP), Službeni list EU, L 162, 21. lipnja 2008., str. $39-40$.

32 Ograničenje odgovornosti za štetu zakonskih revizora može se odrediti: a) određivanjem najvišega novčanog iznosa ili jednadžbe za izračun tog iznosa, do kojega zakonski revizor odgovara za naknadu štete, b) određivanjem niza načela na temelju kojih je zakonski revizor odgovoran samo za štetu koja je nastala njegovim stvarnim doprinosom nastanku štete oštećeniku te stoga nije solidarno odgovoran s drugim štetnicima te c) donošenjem odredbe kojom se subjektu revizije i zakonskom revizoru daje mogućnost ograničiti tu odgovornost ugovorom o reviziji. U slučaju izbora ove posljednje metode ograničenja odgovornosti za štetu, države članice EU-a moraju osigurati: a) sudsku kontrolu ugovora o reviziji, b) o ograničenju odgovornosti zakonskog revizora u subjektu revizije moraju zajednički odlučiti članovi uprave, odnosno izvršni direktori te članovi nadzornog, odnosno upravnog odbora tog subjekta te tu odluku mora potvrditi glavna skupština, odnosno članovi (skupština) subjekta revizije te c) ograničenje odgovornosti za štetu zakonskog revizora i svaka izmjena sporazuma o tomu moraju biti objavljeni u bilješkama uz financijska izvješća subjekta revizije (t. 6. Preporuke). Prije usvajanja neke od predloženih ili neke druge metode ograničenja odgovornosti za štetu zakonskog revizora sukladno Preporuci, država članica EU-a mora uzeti u obzir utjecaj na tržište kapitala i ulagatelje te na uvjete za pristup tržištu zakonske revizije za uvrštena društva, kao i utjecaj na kvalitetu revizije, osigurljivost rizika te subjekte revizije (t. 7. Preporuke). Države članice EU-a moraju obavijestiti Europsku komisiju o poduzetim mjerama u skladu s Preporukom (t. 8. Preporuke). Vidi u Mićović, M., Bukovac Puvača, M., op. cit., str. 160. 
na to pitanje primjenjuju opće odredbe o odgovornosti za štetu iz Zakona o obveznim odnosima (dalje: ZOO). ${ }^{33}$ ZRev u čl. 60. i 61. propisuje obvezu revizorskog društva sklopiti ugovor o osiguranju od odgovornosti za štetu koja može nastati subjektu revizije i trećim osobama pri obavljanju revizorskih usluga te propisuje najmanju svotu pokrića. Njegove su odredbe relevantne i za određenje obveza koje zakonski revizor ima pri pružanju usluga subjektu revizije.

\subsection{Revizorsko društvo kao štetnik}

U ulozi štetnika pojavljuje se revizorsko društvo koje je imenovano za zakonskog revizora i koje je sklopilo ugovor o reviziji sa subjektom revizije. Radi obavljanja revizorskih usluga revizorsko društvo određuje glavnoga revizijskog partnera, ${ }^{34}$ ovlaštene revizore ${ }^{35}$ te druge osobe koje nisu ovlašteni revizori, ${ }^{36}$ a koje obavljaju zakonsku reviziju u subjektu revizije u ime revizorskog društva (čl. 54. st. 1. ZRev). ${ }^{37}$ Oni su radnici u revizorskom društvu, pa se stoga primjenjuje odredba čl. 1061. ZOO-a o odgovornosti poslodavca za rad radnika. Za štetu koju radnik u radu ili u svezi s radom prouzroči trećoj osobi odgovara poslodavac kod kojega je radnik radio $u$ trenutku prouzročenja štete. Odgovornost poslodavca se predmnijeva, osim ako on dokaže da su postojali razlozi koji isključuju odgovornost radnika (čl. 1061. st. 1. ZOO). Oštećenik u tom slučaju zahtijeva popravljanje štete od poslodavca (revizorskog društva). Iznimno, ako je radnik štetu prouzročio namjerno, oštećenik će moći zahtijevati popravljanje štete i izravno od radnika (čl. 1061. st. 2. ZOO). U tom slučaju oštećenik može birati hoće li zahtjev za popravljanje štete usmjeriti prema poslodavcu, radniku ili istodobno protiv oboje. Poslodavac koji je oštećeniku nadoknadio štetu ima pravo zahtijevati od radnika naknadu troškova popravljanja štete, ako je radnik štetu prouzročio namjerno ili iz krajnje nepažnje (čl. 1061. st. 3. ZOO). Takav zahtjev poslodavac mora postaviti prema radniku u roku od šest mjeseci od dana kad je šteta popravljena (čl. 1061. st. 4. ZOO). ${ }^{38}$

33 Zakon o obveznim odnosima, Narodne novine, br. 35/05, 41/08, 125/11, 78/15, 29/18.

34 Glavni je revizijski partner ovlašteni revizor koji je glavna odgovorna osoba za obavljanje zakonske revizije ili drugih revizorskih usluga u ime revizorskog društva te koji potpisuje izvješće o reviziji (čl. 4. t. 22. ZRev). On je radnik revizorskog društva koje je imenovano za zakonskog revizora određenog subjekta revizije.

35 Ovlašteni revizor je fizička osoba koja ima odobrenje za rad koje je izdalo Ministarstvo financija u skladu s odredbama ZRev-a te mora biti zaposlen u revizorskom društvu. On ne može sklopiti ugovor o radu niti smije za svoj ili tuđi račun na bilo koji drugi način obavljati revizorske usluge s drugim revizorskim društvom (čl. 4. t. 9. i čl. 5. st. 3. ZRev). Revizorsko društvo mora imati najmanje jednoga zaposlenog ovlaštenog revizora, a ako se radi o obavljanju zakonske revizije u subjektima od javnog interesa ono mora imati zaposlena u punom radnom vremenu najmanje tri ovlaštena revizora (čl. 5. st. 1. i čl. 63. ZRev).

36 U obavljanju pojedinih revizorskih usluga u revizorskom društvu mogu sudjelovati i osobe koje nisu ovlašteni revizori ako njihov rad planira i nadzire glavni revizijski partner (čl. 5. st. 5. ZRev).

37 Jurić, D., Neovisnost zakonskog revizora u odnosu na subjekte revizije prema Zakonu o reviziji iz 2017. godine, Zbornik Pravnog fakulteta Sveučilišta u Rijeci, vol. 39, br. 1, 2018., str. 145.

38 Gorenc, V., et al., Komentar Zakona o obveznim odnosima, RRIF plus, Zagreb, 2005., str. $1640-1642$. 
Zakon o reviziji posebnu pozornost posvećuje jačanju neovisnosti ovlaštenih revizora i revizorskih društava u odnosu na subjekte revizije. U tu se svrhu uvode stroži zahtjevi za neovisnost i objektivnost te se propisuju organizacijski zahtjevi koje moraju ispunjavati ovlašteni revizori i revizorska društva. Kada se radi o zakonskoj reviziji u subjektima od javnog interesa, propisuju se posebni zahtjevi koji se odnose na obvezu rotacije ovlaštenih revizora i revizorskih društava, određivanje zabranjenih nerevizorskih usluga, ograničenje iznosa naknada za dopuštene nerevizorske usluge, jačanje uloge i proširenje ovlasti revizijskog odbora u subjektima od javnog interesa te suradnja ovlaštenih revizora i revizorskih društava s Ministarstvom financija kao javnim nadzornim tijelom. Ovi zahtjevi imaju za cilj spriječiti pojavu nepravilnosti i nezakonitosti u radu zakonskih revizora, što za posljedicu može imati nastanak njihove odgovornosti prema subjektima revizije i trećim osobama. Ti se zahtjevi primjenjuju prije, tijekom te nakon prestanka revizijskog angažmana. ${ }^{39}$

Prije prihvaćanja, odnosno produljenja revizijskog angažmana revizorsko društvo i ovlašteni revizor moraju procijeniti i dokumentirati: a) ispunjavaju li zahtjeve koji se odnose na njihovu neovisnost u odnosu na subjekta revizije iz čl. 48. i 49. ZRev-a, b) postoje li prijetnje njihovoj neovisnosti i zaštitne mjere koje su primijenjene kako bi se ublažile te prijetnje, c) ima li revizorsko društvo stručne radnike, vrijeme i resurse potrebne za obavljanje revizorske usluge na primjeren način te d) ima li glavni revizijski partner, kojega je imenovalo revizorsko društvo, odobrenje za rad u državi članici EU-a u kojoj se obavlja zakonska revizija (čl. 52. ZRev). Ako te uvjete ne ispunjavaju, ne smiju prihvatiti obavljanje revizorskih usluga u subjektu revizije. Eventualnu pojavu sukoba interesa i odnosa koji ugrožavaju njihovu neovisnost moraju pratiti i tijekom trajanja revizijskog aranžmana te o tomu obavještavati subjekta revizije i Ministarstvo financija te poduzimati potrebne mjere radi sprječavanja njihovog utjecaja na neovisnost zakonskog revizora. Revizorsko društvo, ovlašteni revizor, glavni revizijski partner i svaka osoba koja može izravno ili neizravno utjecati na rezultat revizorskih usluga, moraju tijekom razdoblja koje obuhvaćaju financijska izvješća koja su predmet zakonske revizije i tijekom obavljanja revizorskih usluga biti neovisni u odnosu na subjekta revizije te ne smiju sudjelovati u donošenju odluka subjekta revizije (čl. 48. st. 1. ZRev).

Revizorsko društvo, ovlašteni revizori te druge osobe koje nisu ovlašteni revizori, a sudjeluju u obavljanju revizorskih usluga, moraju djelovati u skladu s temeljnim načelima profesionalne etike o integritetu, objektivnosti, profesionalnoj kompetentnosti i dužnoj pozornosti (čl. 47. st. 1. ZRev). Pri obavljanju revizorskih usluga moraju zadržati profesionalnu skeptičnost te moraju biti svjesni mogućnosti postojanja bitno pogrešnog prikazivanja zbog činjenica ili ponašanja koja upućuju na nepravilnosti, uključujući prijevaru ili pogreške, neovisno o proteklom iskustvu revizorskog društva i ovlaštenog revizora o iskrenosti i integritetu članova uprave, odnosno izvršnih direktora ili članova nadzornog, odnosno upravnog odbora subjekta revizije (čl. 47. st. 2. ZRev). Profesionalne skeptičnosti osobito se moraju pridržavati pri provjeravanju procjena upravljačkih struktura u svezi $\mathrm{s}$ fer vrijednostima, umanjenjem imovine, rezerviranjima i budućim tokom novca relevantnima za

39 Jurić, D., op. cit., str. 138-151. 
sposobnost subjekta za vremenski neograničeno poslovanje (čl. 47. st. 3. ZRev). Oni moraju pri ispunjavanju svojih obveza postupati s povećanom pozornošću, prema pravilima struke i običaja (pažnja dobrog stručnjaka), budući da djeluju kao profesionalci (čl. 20. st. 2. ZOO). ${ }^{40}$

Revizorsko društvo mora sastaviti izvješće o reviziji godišnjih financijskih izvješća ili godišnjih konsolidiranih financijskih izvješća subjekta revizije u skladu s Međunarodnim revizijskim standardima, odredbama ZRev-a i drugim propisima (čl. 58. st. 1. ZRev). U njemu zakonski revizor daje neovisno stručno mišljenje o tomu prikazuju li financijska izvješća u svim bitnim odrednicama istinit i fer prikaz financijskog položaja i uspješnosti poslovanja te novčanih tokova u skladu s primjenjivim okvirom financijskog izvještavanja ili, ako je to primjenjivo, jesu li financijska izvješća u skladu s propisima (čl. 4. t. 2. ZRev). Izvješće o reviziji mora biti u pisanom obliku te sadržavati propisane bitne sastojke (čl. 58. st. 2. ZRev). ${ }^{41}$ Revizorsko mišljenje glavni je dio izvješća o reviziji, a može biti pozitivno, s rezervom ili negativno. Ako ovlašteni revizor ili revizorsko društvo nije u mogućnosti izraziti revizorsko mišljenje, revizorsko izvješće sadrži navod o suzdržavanju od izražavanja mišljenja (čl. 58. st. 3. ZRev). Odgovornost zakonskog revizora za štetu može nastati kada da pozitivno mišljenje, a naknadno se utvrdi da financijsko stanje subjekta revizije nije onakvo kakvo je bilo prikazano u revidiranim godišnjim financijskim izvješćima. Pogrešno mišljenje će postojati ako je zakonski revizor dao pozitivno mišljenje, a trebao je dati mišljenje s rezervom, negativno mišljenje ili se trebao suzdržati od izražavanja mišljenja. Pritom pogrešno mišljenje mora biti rezultat njegova protupravnog postupanja, što znači da je zakonski revizor postupao protivno propisima i pravilima struke, odnosno bez upotrebe pažnje dobrog stručnjaka. ${ }^{42}$

Valja naglasiti da se revizija godišnjih financijskih izvješća ili godišnjih konsolidiranih financijskih izvješća subjekata revizije provodi tako da se osigura razumno uvjerenje o otkrivenim bitnim pogreškama u financijskim izvješćima. Zakonski revizor ne jamči za točnost podataka sadržanih u financijskim izvješćima. ${ }^{43}$ Okvir financijskog izvještavanja koji je primijenjen pri sastavljanju godišnjih financijskih izvješća ili godišnjih konsolidiranih financijskih izvješća subjekta revizije određuje njegova uprava, odnosno izvršni direktori. Oni odgovaraju i za točnost podataka u financijskim izvješćima. ${ }^{44}$ Zakonski revizor sam ocjenjuje u kolikoj će mjeri ispitivati transakcije i koje će dokaze pribavljati pri obavljanju zakonske revizije u svakom konkretnom slučaju. Pritom u izvješću o reviziji mora opisati opseg

40 Pri procjeni jesu li postupali s takvom pozornošću u obzir se uzimaju pravila Međunarodnih revizijskih standarda, Kodeks profesionalne etike revizora, smjernice Hrvatske revizorske komore te odredbe ZRev-a. Vidi u Mićović, M., Bukovac Puvača, M., op. cit., str. 171-173.

41 Izvješće o reviziji mora potpisati najmanje ovlašteni revizor koji obavlja zakonsku reviziju (glavni revizijski partner) i zastupnik po zakonu revizorskog društva (čl. 58. st. 5. ZRev). Njemu se prilažu godišnja financijska izvješća ili druga izvješća koja su bila predmet zakonske revizije (čl. 58. st. 12. ZRev).

42 Ibid., str. 171.

43 To bi zahtijevalo ispitivanje svih transakcija i pribavljanje brojnih dokaza tijekom obavljanja zakonske revizije, što je neekonomično.

44 Primijenjeni okvir financijskog izvještavanja mora biti naznačen u izvješću o reviziji. 
zakonske revizije i navesti revizijske standarde koje je primijenio pri obavljanju zakonske revizije. Mišljenje zakonskog revizora izraženo u izvješću o reviziji odnosi se na godišnja financijska izvješća kao cjelinu, što znači da se odnosi i na one transakcije koje nisu bile obuhvaćene njegovim ispitivanjem (čl. 58. st. 9. ZRev). Stoga se radi utvrđivanja njegove odgovornosti za štetu mora ispitati je li zakonski revizor stvarno obavio sve postupke koje je prema revizijskim standardima trebao obaviti. Zakonski revizor ispituje sadrže li financijska izvješća bitne nepravilnosti (pogreške i prijevare) te prema svojoj stručnoj prosudbi ocjenjuje koje nepravilnosti imaju takvo svojstvo. On svoju pozornost usmjerava na materijalno važne podatke. Bitan će biti onaj podatak čije izostavljanje ili pogrešno prikazivanje može uvjetovati pogrešnu odluku ili prosudbu korisnika financijskih izvješća. Kada uoči pogreške ili prijevare u revidiranim financijskim izvješćima mora ocijeniti njihov učinak na financijska izvješća i o tomu obavijestiti upravne i nadzorne organe subjekta revizije. Ako između njih postoji nesuglasje u pogledu uočene pogreške ili prijevare, zakonski revizor može i odustati od preuzete obveze revizije..$^{45}$

Što se tiče opsega revizije godišnjih financijskih izvješća i godišnjih konsolidiranih financijskih izvješća, ono ne obuhvaća izražavanje uvjerenja o budućoj održivosti subjekta revizije ili učinkovitosti članova uprave, izvršnih direktora ili upravnog odbora pri dotadašnjem ili budućem vođenju poslova subjekta revizije (čl. 55. ZRev). Time se žele otkloniti pogrešne predodžbe trećih osoba u svezi s ulogom zakonskih revizora te dodatno ukazati da za točnost i pouzdanost sadržaja godišnjih financijskih izvješća odgovaraju članovi upravnih i nadzornih organa subjekta revizije. ${ }^{46}$

Odgovornost revizorskog društva za štetu nastalu subjektu revizije može proizaći i iz povrede obveze čuvanja revizorske tajne. Revizorsko društvo mora kao revizorsku tajnu čuvati sve podatke koje je saznalo obavljajući revizorske usluge (čl. 57. st. 1. ZRev) ${ }^{47}$ Obvezom čuvanja revizorske tajne vezani su članovi uprave i nadzornog odbora, odnosno izvršni direktori i članovi upravnog odbora revizorskog društva, kao i osobe koje rade ili su radile u revizorskom društvu i kojima jesu ili su bili na bilo koji način dostupni podatci obuhvaćeni revizorskom tajnom. Oni se tim podatcima ne smiju koristiti za svoj račun niti ih priopćiti trećim osobama ili im omogućiti da se njima koriste (čl. 57. st. 3. ZRev). U određenim slučajevima dopušteno je priopćavanje tih podataka (čl. 57. st. 4. ZRev). ${ }^{48}$ Time se štiti odnos povjerljivosti

45 Ibid., str. 174-175.

46 Ibid., str. 168-169.

47 Revizorska tajna smatra se poslovnom tajnom revizorskog društva. U odnosu na glavnoga revizijskog partnera, ovlaštene revizore i druge osobe koje su sudjelovale u obavljanju zakonske revizije ona ima obilježje profesionalne tajne. Ona se čuva u skladu sa Zakonom o zaštiti tajnosti podataka, osim ako ZRev-om nije određeno drukčije (čl. 57. st. 2. ZRev). Ako se tijekom obavljanja revizorskih usluga revizorsko društvo treba koristiti dokumentacijom, podatcima i informacijama koji su klasificirani odgovarajućim stupnjem tajnosti, moraju se primijeniti odredbe Zakona o tajnosti podataka i Zakona o informacijskoj sigurnosti (čl. 57. st. 5. ZRev).

48 To će biti slučajevi kada se podatci priopćavaju trećim osobama uz prethodnu pisanu suglasnost subjekta revizije, Ministarstvu financija radi provedbe nadzora, odnosno drugih postupaka u okvirima njegove nadležnosti, drugom revizorskom društvu u svrhu obavljanja 
između revizorskog društva i subjekta revizije te se štite njegovi podatci, a koje su navedene osobe u revizorskom društvu saznale obavljajući revizorske usluge.

\subsection{Oštećenici}

U ulozi oštećenika mogu se pojaviti subjekt revizije (ugovorna odgovornost za štetu revizorskog društva) te treće osobe izvan subjekta revizije koje se pojavljuju kao korisnici izvješća o reviziji (izvanugovorna odgovornost za štetu revizorskog društva).

U ime subjekta revizije zahtjev za naknadu štete prema revizorskom društvu podnosi njegova uprava, odnosno izvršni direktori. ${ }^{49}$ Ako je nad subjektom revizije pokrenuta likvidacija, to čine likvidatori društva, a ako je nad njime otvoren stečajni postupak to čini stečajni upravitelj. To proizlazi iz odredbi ZTD-a i Stečajnog zakona o osobama koje su ovlaštene zastupati trgovačka društva. Zahtjev za naknadu štete u ime subjekta revizije koji je društvo kapitala ne mogu podnijeti njegovi dioničari, odnosno članovi, budući da ga oni nisu ovlašteni zastupati. ${ }^{50}$ Oni moraju dokazati štetnu radnju, nastalu štetu te uzročnu vezu između štete i štetne radnje. Revizorsko društvo odgovara za svaki stupanj krivnje (namjera, krajnja i obična nepažnja). Predmnijeva se samo obična nepažnja, a namjera i krajnja nepažnja se moraju dokazati. ${ }^{51}$ Šteta se može sastojati u umanjenju imovine (obična šteta), sprječavanja njezinog povećanja (izmakla korist) te neimovinske štete (npr. povreda poslovnog ugleda, poslovne tajne i sl.) koja je nastala subjektu revizije. Štetna radnja mora biti rezultat protupravnog postupanja revizorskog društva pri pružanju revizorskih usluga. ${ }^{52}$ To znači da revizorsko društvo odgovara po kriteriju predmnijevane krivnje, a njegova odgovornost počiva na povredi obveze iz ugovora o reviziji kojega je sklopilo sa subjektom revizije. ${ }^{53}$

revizije godišnjih konsolidiranih financijskih izvješća u skladu sa ZRev-om, sudu na njegov pisani zahtjev u kaznenom postupku ili postupku koji mu prethodi, nadležnom tijelu radi sprječavanja pranja novca i financiranja terorizma, ako je to propisano drugim zakonom ili pravno obvezujućim aktima EU-a te tijelima ovlaštenim za nadzor poslovanja subjekata od javnog interesa, u okvirima njihove nadležnosti.

49 Ako je subjekt revizije komanditno društvo to čine njegovi komplementari koji su ga ovlašteni zastupati.

50 Time se isključuje mogućnost podnošenja, tzv. derivativnih tužbi. Šteta nastala subjektu revizije utječe i na tržišnu vrijednost dionica, odnosno poslovnih udjela društva koje drže njegovi dioničari, odnosno članovi. Time im nastaje, tzv. refleksna šteta. Dioničar, odnosno član subjekta revizije ne može samostalno podnijeti zahtjev za naknadu te refleksne štete, već to mora učiniti subjekt revizije. Vidi u Barbić, J., Pravo društava, Knjiga druga - društva kapitala, Svezak I.: dioničko društvo, Organizator, Zagreb, 2010., str. 806-807.

51 O dokazanom stupnju krivnje ovisi opseg naknade štete. Ako se dokaže postojanje prijevare, namjere ili krajnje nepažnje, štetnik odgovara za cjelokupnu štetu. Ako je šteta nastala zbog obične nepažnje, koja se predmnijeva, štetnik odgovara samo za predvidivu štetu (čl. 346. ZOO). Vidi u Gorenc, V. et al., op. cit., str. 511-515.

52 Revizorsko se društvo može osloboditi odgovornosti za štetu ako dokaže da šteta nije nastala ili da nije bilo njegove krivnje, odnosno da je postupalo u skladu s propisima i pravilima struke te s pažnjom dobrog stručnjaka.

53 Gorenc, V. et al., op. cit., str. 45-48, 503-517, 1604-1616 i 1622-1625. 
Pod istim pretpostavkama zahtjev za naknadu štete prema revizorskom društvu mogu podnijeti i treće osobe koje se pojavljuju kao korisnici izvješća o reviziji (vjerovnici subjekta revizije, trgovačka društva koja su povezana sa subjektom revizije, ulagatelji i kreditori subjekta revizije, javnost i sl.). ${ }^{54}$ Pritom će oni biti u nepovoljnijem položaju u pogledu dokazivanja uzročne veze između nastale štete i štetne radnje revizorskog društva. To je zbog toga što nastanak njihove štete proizlazi iz financijskog stanja u subjektu revizije, a za to odgovaraju članovi njegovih upravnih i nadzornih organa.$^{55}$ Objava revizorovog pogrešnog mišljenja nije dovoljna za dokazivanje postojanja uzročne veze između njegove štetne radnje i štete koja je nastala trećim osobama. Potrebno je stoga dokazati vezu između financijskog stanja u subjektu revizije i pogrešnog mišljenja koje je revizorsko društvo iskazalo u izvješću o reviziji te vezu između pogrešnog mišljenja i radnje koji je oštećenik poduzeo ili propustio poduzeti, uslijed čega mu je nastala šteta. Ako oštećenik uspije dokazati da je revizorsko društvo sudjelovalo u pogrešnom prikazivanju financijskog stanja u subjektu revizije (zakonski je revizor znao ili morao znati za to), nalazi se u povoljnijem položaju. To znači da je revizorsko društvo sudionik prijevare te se time uspostavlja njegova odgovornost za štetu prema trećim osobama. U drugim je slučajevima mogućnost ostvarivanja naknade štete od revizorskog društva vrlo mala. ${ }^{56}$

\subsection{Zastara zahtjeva oštećenika za naknadu štete prema revizorskom društvu}

U slučaju ugovorne odgovornosti za štetu zahtjev subjekta revizije za naknadu štete prema revizorskom društvu zastarijeva za vrijeme određeno za zastaru obveze čijom je povredom nastala šteta (čl. 230. st. 3. ZOO). Budući da ugovor o reviziji ima obilježje trgovačkog ugovora o prometu robe i usluga, zahtjev za naknadu štete subjekta revizije zastarijeva u roku od tri godine od kada je šteta nastala (čl. 228. ZOO). U slučaju izvanugovorne odgovornosti za štetu zahtjev treće osobe za naknadu štete prema revizorskom društvu zastarijeva u roku od tri godine od kada je treća osoba doznala za štetu i osobu koja je štetnik (subjektivni rok), odnosno u svakom slučaju u roku od pet godina od kada je šteta nastala (objektivni rok) (čl. 230. st. 1. i 2. ZOO). Ako je šteta prouzročena kaznenim djelom, a za kazneni je progon predviđen dulji rok zastare, zahtjev za naknadu štete prema odgovornoj osobi zastarijeva kad istekne vrijeme određeno za zastaru kaznenog progona (čl. 231. st. 1. ZOO). ${ }^{57}$ Nastupanjem zastare utuživa se obveza na naknadu štete pretvara u neutuživu, a štetnik ima pravo uskratiti ispunjenje svoje obveze. Na zastaru sud ne pazi po službenoj dužnosti, već

54 U slučaju izvanugovorne odgovornosti za štetu, štetnik mora nadoknaditi cjelokupnu štetu bez obzira na stupanj njegove krivnje.

55 Oni odgovaraju za vođenje poslova društva i nadzor nad vođenjem poslova društva, kao i za utvrđivanje godišnjih financijskih izvješća te točnost prikazanoga financijskog stanja subjekta revizije.

56 Mićović, M., Bukovac Puvača, M., op. cit., str. 175-176.

57 Ta će se se odredba primjenjivati ako je kazneni postupak završen osuđujućom presudom. Odgovorna osoba ne mora biti počinitelj kaznenog djela (npr. poslodavac koji odgovara za rad radnika koji je počinitelj kaznenog djela). 
se na nju štetnik mora pozvati u sudskom postupku. ${ }^{58}$ Odredbe ZOO-a o zastari su prisilne naravi. ${ }^{59}$

\subsection{Ograničenje odgovornosti za štetu revizorskog društva}

ZRev ne propisuje ograničenje iznosa do kojega zakonski revizori odgovaraju za štetu počinjenu subjektima revizije i trećim osobama. Stoga bi bilo korisno da se to propiše zakonom, sukladno Preporuci Europske komisije iz 2008. godine, što bi doprinijelo pravnoj sigurnosti te olakšalo poslovanje revizorskih društava i sklapanje ugovora o osiguranju od odgovornosti za štetu s osiguravajućim društvima. To bi se ograničenje odgovornosti primjenjivalo u odnosu na štetu nastalu subjektima revizije i trećim osobama, osim ako je šteta nastala prijevarom ili namjernim postupanjem revizorskog društva pri pružanju revizorskih usluga.

Kada se radi o ugovornoj odgovornosti revizorskog društva za štetu nastalu subjektu revizije, ZOO određuje da se ta odgovornost ugovorom može proširiti, ograničiti ili isključiti (čl. 344. i 345. ZOO). ${ }^{60}$ Ugovorom se ne može isključiti ili ograničiti odgovornost za štetu ako je ona nastala zbog namjere ili krajnje nepažnje štetnika pri povredi ugovornih obveza (čl. 345. st. 1. ZOO). ${ }^{61}$ To znači da se ograničenje odgovornosti za štetu može predvidjeti samo ako je revizorsko društvo uzrokovalo štetu postupajući s običnom nepažnjom. Ipak, takva se egzoneracijska klazula može poništiti odlukom suda, ako takav zahtjev postavi subjekt revizije, a klauzula je rezultat sporazuma ugovornih strana koji je proizašao iz monopolskog položaja revizorskog društva ili uopće iz neravnopravnog odnosa ugovornih strana (čl. 345. st. 2. ZOO).

Egzoneracijska se klauzula može unijeti u ugovor o reviziji ili se o ograničenju odgovornosti revizorskog društva za štetu može sklopiti poseban ugovor prije nastanka štete. ${ }^{62}$ Preporuka iz 2008. godine određuje da u tom slučaju države članice moraju osigurati: a) sudsku kontrolu ugovora o reviziji, b) o ograničenju odgovornosti revizorskog društva za štetu u subjektu revizije moraju zajednički odlučiti članovi uprave, odnosno izvršni direktori te članovi nadzornog, odnosno upravnog odbora tog subjekta te tu odluku mora potvrditi glavna skupština, odnosno članovi (skupština) subjekta revizije te c) ograničenje odgovornosti za štetu revizorskog društva i svaka izmjena sporazuma o tomu mora biti objavljena u bilješkama uz financijska izvješća subjekta revizije (t. 6. Preporuke). Stoga bi trebalo mogućnost ugovornog ograničenja

58 Nastupanjem zastare oštećenik gubi mogućnost prisilnim putem ostvariti naknadu štete pred sudom (pravo na tužbu). U slučaju nastupanja zastare zahtjeva za naknadu štete, oštećenik može zahtijevati od štetnika, po pravilima stjecanja bez osnove, ustupiti mu ono što je štetnik dobio radnjom kojom je prouzročena šteta (čl. 1110. ZOO). Taj tužbeni zahtjev za ustupanje zastarijeva za pet godina od dana nastupanja zastare zahtjeva za naknadu štete (čl. 225. ZOO).

59 Gorenc, V. et al., str. 310-312, 313-317 i 1738-1739.

60 U slučaju proširenja odgovornosti to se neće primijeniti ako bi to bilo protivno načelu savjesnosti i poštenja (čl. 344. st. 2. ZOO). Proširenje, ograničenje ili isključenje odgovornosti za štetu mora se predvidjeti ugovorom prije nastanka štete. Vidi u ibid., str. 508-509.

61 Ugovor s takvom egzoneracijskom klauzulom ili poseban ugovor o ograničenju odgovornosti za štetu u tom slučaju bili bi ništetni. Sud postupa po službenoj dužnosti.

62 Ibid., str. 509-510. 
odgovornosti zakonskog revizora za štetu uskladiti s Preporukom.

ZOO posebno uređuje ograničenje odgovornosti za štetu s obzirom na najviši iznos naknade štete. Takva se klauzula može unijeti u ugovor o reviziji te će ona biti pravovaljana, osim ako taj iznos naknade štete nije u očitom nerazmjeru sa štetom i ako za određeni slučaj nije što drugo određeno zakonom (čl. 345. st. 3. ZOO). Ako je šteta uzrokovana namjerno ili krajnjom nepažnjom revizorskog društva, ograničenje iznosa naknade štete neće se primijeniti, a subjekt revizije ima pravo na naknadu cjelokupne štete (čl. 345 . st. 4 . ZOO) ${ }^{63}$

Odredbe ZOO-a o ugovornom ograničenju odgovornosti za štetu revizorskog društva prema subjektu revizije ne primjenjuju se kada se radi o izvanugovornoj odgovornosti revizorskog društva prema trećim osobama. ${ }^{64}$

\section{OBVEZA OSIGURANJA OD ODGOVORNOSTI ZA ŠTETU ZAKONSKOG REVIZORA}

\subsection{Općenito}

Zakonom o reviziji propisana je obveza revizorskog društva sklopiti i redovito obnavljati ugovor o osiguranju od odgovornosti za štetu koju bi trećim osobama moglo počiniti obavljanjem revizorskih usluga (čl. 60. st. 1. i 3. ZRev). Valjana polica o osiguranju od odgovornosti revizora uvjet je za obavljanje revizorske djelatnosti. Naime, Ministarstvo financija izdaje revizorskom društvu rešenje o odobrenju za rad tek nakon što mu društvo dostavi dokaz o osiguranju (čl. 17. st. 10. ZRev). Isto se zahtijeva i kao uvjet za registraciju revizorskog društva koje ima odobrenje za rad od nadležnog tijela u svojoj matičnoj državi članici EU-a (čl. 25. st. 3. ZRev).

Propisivanje osiguranja od odgovornosti revizorskog društva kao obveznog osiguranja posljedica je velike važnosti revizije kao djelatnosti od javnog interesa te ima za cilj (imovinsku) zaštitu potencijalno velikog broja trećih oštećenih osoba koje postupaju s povjerenjem u rad i mišljenja zakonskih revizora u pogledu financijskih izvješća. ${ }^{65}$

\subsection{Ugovor o osiguranju od odgovornosti revizorskog društva}

Ugovor o osiguranju od odgovornosti revizora može se odrediti kao ugovor kojim se osiguratelj obvezuje revizorskom društvu, kao ugovaratelju osiguranja, da će u granicama svojih obveza propisanih Zakonom o reviziji, odnosno preuzetih ugovorom, trećoj oštećenoj osobi nadoknaditi štetu za koju je prema pravilima građanskoga prava odgovorno revizorsko društvo kao osiguranik, a ugovaratelj osiguranja (revizorsko društvo) obvezuje se platiti premiju osiguranja. ${ }^{66}$

63 Ibid., str. 510-511.

64 Njima revizorsko društvo mora nadoknaditi cjelokupnu štetu bez obzira na stupanj svoje krivnje. Vidi u ibid., str. 513.

65 Ćurković, M., Osiguranje od izvanugovorne i ugovorne (profesionalne) odgovornosti, Inženjerski biro, Zagreb, 2015., str. 15 i 183.

66 Prema Ćurković, M., op. cit., str. 60. 
Revizorsko društvo ima položaj ugovaratelja osiguranja i položaj osiguranika. Ugovaratelj osiguranja osoba je koja sklapa ugovor o osiguranju, a revizorsko društvo, kako je navedeno, mora sklopiti ugovor o osiguranju od odgovornosti te ga redovito obnavljati, odnosno produljivati (čl. 60. st. 3. ZRev). Iznimno se kao ugovaratelj osiguranja može pojaviti i Hrvatska revizorska komora koja u korist svojih članova revizorskih društava (kao osiguranika) sklapa ugovor o osiguranju od odgovornosti (čl. 61. st. 3. ZRev). U tom slučaju radi se o, tzv. kolektivnim ugovorima o osiguranju od odgovornosti koje sklapa Komora za svoje članstvo. Prednost takvih ugovora o osiguranju od odgovornosti je da se pokriće ne mora prilagođavati svakom pojedincu, već se ono dogovara samo s Komorom, osiguranicima se omogućuju povoljniji uvjeti osiguranja, niže premije i šire pokriće. No takvo kolektivno ugovaranje pokrića ima i loše strane jer ne odgovora specifičnostima rizika kojima su izloženi pojedini članovi osiguranici (npr. istom policom osigurani su članovi s malim opsegom posla i članovi s velikim opsegom posla uz jednaku svotu osiguranja). ${ }^{67}$

Osiguranik je osoba čija je odgovornost za štetu pokrivena osiguranjem, a to je opet revizorsko društvo. S gledišta pravila osiguranja nije nedopušteno da ista osoba bude ugovaratelj osiguranja i osiguranik, tj. da ugovaratelj osiguranja „pokrije“ vlastitu odgovornost.

Osiguratelj je pravna osoba, trgovačko društvo (dioničko društvo za osiguranje ili društvo za uzajamno osiguranje) koje je dobilo dozvolu HANFE obavljati poslove osiguranja od odgovornosti. Revizorsko društvo samo odlučuje kod kojeg će osiguratelja sklopiti ugovor o osiguranju od odgovornosti, ovisno o ponuđenim uvjetima osiguranja i premiji. Obveza sklapanja ugovora o osiguranju od odgovornosti je na strani revizorskog društva, a ne osiguratelja. Stoga ako revizorsko društvo želi sklopiti ugovor o osiguranju od odgovornosti mora prihvatiti uvjete i premiju koju mu nudi osiguratelj. No, osim kod osiguravajućih društava u Republici Hrvatskoj, revizorsko društvo može se odlučiti na sklapanje ugovora o osiguranju od odgovornosti u drugoj državi članici EU-a. U tom slučaju jednakovrijedno osiguranje od odgovornosti za štetu koje je sklopljeno u drugoj državi članici priznaje se i u Republici Hrvatskoj (čl. 60. st. 2. ZRev).

U pogledu osiguranja od odgovornosti revizorsko društvo ima i određene obveze prema Ministarstvu financija (čl. 60. st. 2 ZRev): a) dostaviti presliku police osiguranja koja se odnosi na produljenje ugovora o osiguranju od odgovornosti i b) izvijestiti o svakoj promjeni koja nastane tijekom osiguranja (npr. promjena osiguratelja, promjena uvjeta osiguranja, premije, pokrića, itd.).

Navedene obveze prema Ministarstvu financija revizorsko društvo mora izvršiti u roku od osam dana od sklapanja police osiguranja (tj. produljenja ugovora o osiguranju od odgovornosti) ili od dana nastale promjene tijekom osiguranja.

Stoga se nameće pitanje što ako revizorsko društvo nije Ministarstvu financija dostavilo presliku police o produljenju osigurateljskog pokrića. U tom slučaju Ministarstvo financija mora pozvati revizorsko društvo da u roku od 15 dana od poziva dostavi dokaz o osiguranju. Ako po isteku toga roka ne dostavi dokaz o osiguranju, Ministarstvo financija izriče nadzornu mjeru privremene zabrane ovlaštenom revizoru, 
revizorskom društvu i glavnom revizijskom partneru za obavljanje zakonskih revizija i/ili potpisivanje revizorskog izvješća, pritom postupajući po odredbama propisa kojima se uređuje prekršajni postupak (čl. 60. st. 4., u vezi s čl. 94. st. 1. toč. 4. ZRev).

\subsection{Treće osobe u osiguranju od odgovornosti zakonskih revizora}

Kod osiguranja od odgovornosti općenito, pa tako i kod osiguranja od odgovornosti zakonskih revizora, iznimno je bitno pitanje tko se to smatra trećim (oštećenim) osobama. Ovo iz razloga što treće osobe po zakonu imaju vlastito i neposredno tužbu (tzv. actio directa) prema osiguratelju od odgovornosti, do visine ugovorene svote osiguranja (čl. 965. st. 1. i 2. ZOO). To znači da treće (oštećene) osobe mogu izravno od osiguratelja od odgovornosti zahtijevati naknadu štete koju su pretrpjele događajem (osiguranim slučajem) za koji odgovara osiguranik (revizorsko društvo).

Načelno govoreći, trećim osobama smatraju se osobe koje nisu ugovorne strane ugovora o osiguranju od odgovornosti. Prema Uvjetima za osiguranje od odgovornosti osoba ovlaštenih za pružanje usluga revizije Hrvatskog ureda za osiguranje iz 2011. godine (dalje Uvjeti HUO) ${ }^{68}$ treća osoba je oštećena osoba koja nije ugovorna strana ugovora o osiguranju, odnosno osoba za koju osiguranik na temelju ugovora o reviziji obavlja usluge revizije (pojam u odlomku br. 5., u dijelu Uvjeta HUO koji nosi naziv „Značenje pojedinih izraza“). Prema čl. 1. st. 1.2., odlomak 5 Općih uvjeta za osiguranje od odgovornosti revizora ERGO osiguranje d.d. iz 2018. godine (dalje: Uvjeti ERGO) oštećenikom (dakle, trećom osobom) smatra se pravna ili fizička osoba kojoj je prouzročena šteta koja je posljedica revizije koju je obavljao osiguranik. Također, trećom oštećenom osobom smatra se i osoba koja ima pravo postaviti zahtjev za naknadu štete koju mu je prouzročio osiguranik.

S obzirom na izneseno, može se zaključiti kako se radi o neodređenom broju osoba koje mogu imati položaj treće osobe (tzv. negativno određivanje pojma trećih osoba). To su uvijek one osobe koje imaju ujedno i položaj oštećenika, odnosno one koju su pretrpjele štetu zbog propusta ili pogreške u obavljanju djelatnosti revizije. Primjerice, ovdje spadaju: trgovačko društvo, odnosno subjekt nad kojim se provodi revizija te ostale treće osobe koje se javljaju kao korisnici izvješća o reviziji (vjerovnici, povezana trgovačka društva, ulagatelji, kreditori, javnost i sl.) (supra 4.2.).

\subsection{Predmet osiguranja (osigurani rizik)}

Predmet osiguranja odgovornost je osiguranika za štetu koja je prouzročena trećim osobama pri obavljanju usluga / djelatnosti revizije (čl. 1. Uvjeta HUO, čl. 7. st. 7.1. Uvjeta ERGO). Osiguranje od odgovornosti revizora temelji se na općim pravilima odgovornosti za štetu sukladno ZOO-u, a koja su ranije detaljno obrađena u radu (supra 4.1.). Ako prema navedenim pravilima ne postoji odgovornost revizora

68 Iz preambule Uvjeta HUO: „Objavljivanjem Uvjeta za osiguranje od odgovornosti osoba ovlaštenih za pružanje usluga revizije Hrvatski ured za osiguranje ne preporučuje njihovu doslovnu primjenu. Društva za osiguranje slobodna su ugovarateljima osiguranja ponuditi Uvjete različite od ovdje objavljenih.“ 
(osiguranika), neće postojati niti odgovornost osiguratelja od odgovornosti. Potrebno je napomenuti da se predmet osiguranja odnosi samo na, tzv. čisto imovinsku štetu. To je šteta koja je nastala obavljanjem djelatnosti revizije, a nije posljedica oštećenja ili uništenja stvari, odnosno smrti, povrede tijela ili narušavanja zdravlja (pojam u odlomku br. 7., u dijelu Uvjeta HUO koji nosi naziv „Značenje pojedinih izraza“, čl. 1. st. 1.2., odlomak br. 15 Uvjeta ERGO).

\subsection{Isključenja iz pokrića}

Isključenje pokrića znači da osiguratelj od odgovornosti ne odgovara za pojedine štete koje bi nastale u određenim slučajevima (tj. ne postoji njegova obveza naknade štete). Uvjetima osiguranja predviđeni su brojni slučajevi takvih isključenja od odgovornosti. Mogu se podijeliti na, tzv. opća isključenja iz pokrića te na isključenja koja su specifična za osiguranje od odgovornosti revizora.

Među opća isključenja spadaju: štete koje su prouzročene ratom i sličnim događajima (revolucija, ustanak itd.), građanskim nemirima, nasiljem, mjerama konfiskacije ili rekvizicije, djelovanjem nuklearne energije, ionizirajućim zračenjem, svemirskim materijalom, djelovanjem energije sunca, vulkana, potresa, prirodnih sila i sl. Potom ovdje spadaju štete zbog uništenja ili oštećenja stvari te zbog smrti, tjelesne ozljede i narušavanja zdravlja osoba (čl. 12. st. 12.3 Uvjeta ERGO, čl. 3. toč. 1., 10. i 11. Uvjeta HUO).

Među posebna isključenja koja su karakteristična za osiguranje od odgovornosti zakonskih revizora spadaju: šteta prouzročena zbog toga jer je osiguranik propustio obaviti plaćanje za koje je bio ovlašten (plaćanje poreza, doprinosa, računa i slično); šteta prouzročena osobi koja je povezana s osiguranikom (povezane pravne osobe su one u kojima osiguranik ima udio ili koje u društvu osiguranika imaju udio veći od 25 $\%$ temeljnoga kapitala; povezane fizičke osobe su osiguranik i osiguranikovi roditelji, braća i sestre, djeca, bračni ili izvanbračni partner, članovi kućanstva); šteta prouzročena pravnoj ili fizičkoj osobi u kojoj osiguranik ili djelatnici osiguranika imaju ovlasti rukovođenja i upravljanja (direktori, ravnatelji, članovi uprave ili nadzornog odbora i slično); šteta prouzročena za vrijeme dok revizorsko društvo ili samostalni revizor nemaju valjane licence, dozvole za rad i slično; štete zbog prijevare, prisile, prijetnje ili drugih kažnjivih dijela; štete zbog ugovornog proširenja odgovornosti osiguranika i na slučajeve kad po zakonu ne odgovara; štete koje su prouzročene namjerno ili krajnjom nepažnjom osiguranika ili zbog šteta nastalih kao posljedica svjesnog postupanja suprotno propisima po kojima se obavlja osiguranikova djelatnost; štete koje su posljedica nesolventnosti ili nelikvidnosti osiguranika, odnosno prestanka obavljanja djelatnosti; štete zbog neodržavanja ugovorenih i zakonskih rokova ako je za to odgovoran osiguranik, odnosno njegova ovlaštena osoba itd. (čl. 12., st. 12.4 Uvjeta ERGO, čl. 3. toč. 2.-9. i toč. 13. Uvjeta HUO).

\subsection{Osigurani slučaj}

Osigurani slučaj općenito, pa tako i u osiguranju od odgovornosti događaj je koji je prouzročen osiguranim rizikom (čl. 922. st. 1. ZOO). Za razliku od osiguranog 
rizika koji mora biti budući, neizvjestan i nezavisan o isključivoj volji ugovaratelja osiguranja ili osiguranika (zakonskog revizora), osigurani slučaj je stvarni događaj koji je nastupio.

S obzirom na to da je osigurani rizik, odnosno predmet osiguranja odgovornost zakonskog revizora za obavljanje djelatnosti revizije (supra 5.4.), osigurani je slučaj propust ili pogreška revizora (tj. osiguranika) koja ima za posljedicu nastanak štete trećoj (oštećenoj) osobi. Sukladno tomu smatra se da je osigurani slučaj nastao onda kada je osiguranik skrivljeno povrijedio neku od svojih propisanih dužnosti revizora, odnosno kada se ostvario propust ili pogreška u obavljanju poslova revizije (čl. 2. st. 1. Uvjeta HUO, čl. 8. st. 8.3. i st. 8.5. Uvjeta ERGO).

Nije potrebno posebno naglašavati kako je ugovor o osiguranju od odgovornosti revizora ništetan ako je u trenutku njegova sklapanja već nastao osigurani slučaj (propust ili pogreška zakonskog revizora), ili je taj bio u nastupanju, ili je bilo izvjesno da će nastupiti, ili je prestala mogućnost da on nastane (čl. 922. st. 3. ZOO).

Posebnu pozornost valja posvetiti razlikovanju osiguranog slučaja kod uzastopnih šteta od osiguranog slučaja kod serijskih šteta. U prvom slučaju, tijekom trajanja ugovora o osiguranju od odgovornosti pojavljuje se više šteta koje nemaju isti uzrok pa je svaka od njih zasebni osigurani slučaj. U tom slučaju, osigurnina za svaki osigurani slučaj koji je nastupio isplaćuje se s obzirom na cijeli iznos osiguranja, bez njegova umanjenja za iznos prije isplaćenih naknada u tom razdoblju (čl. 949. st. 6 . ZOO, čl. 8. st. 8.8. Uvjeta ERGO). U drugom slučaju (serijske štete), ako tijekom trajanja osigurateljskog pokrića nastupi više šteta koje imaju isti ili istovrsni uzrok, odnosno čiji je nastanak posljedica jednog vremenski i uzročno povezanog događaja, sve te povezane štete čine jedan osigurani slučaj ${ }^{69} \mathrm{i}$ to bez obzira na broj oštećenih osoba (čl. 2. st. 3. Uvjeta HUO). U tom se slučaju smatra da je osigurani slučaj nastupio kada je nastala prva šteta u seriji, a osiguratelj je u obvezi maksimalno do ugovorene jedne svote osiguranja. Pogreška i propust u obavljanju postupka revizije ima za posljedicu pogreške i propuste $u$ davanju revizorskih mišljenja, pa bi se u tom smislu radilo o jednom osiguranom slučaju (serijskim štetama), a ne o više njih, jer pogreška/propust u revizijskom izvješću stoji u uzročnoj vezi s ranijom pogreškom/ propustom u obavljanju postupka revizije.

\subsection{Specifična obveza osiguranika glede pridržavanja zaštitnih mjera radi sprječavanja nastupa osiguranog slučaja}

Opće je pravilo ugovornog prava osiguranja da je osiguranik dužan poduzeti sve potrebne mjere (propisane, ugovorene ili razborite) da spriječi nastanak osiguranog slučaja (čl. 950. st. 1 ZOO-a). Ako osiguranik tu svoju obvezu ne ispuni, obveza osiguratelja smanjuje se za onoliko za koliko je nastala šteta veća zbog toga neispunjenja (čl. 950. st. 4. ZOO), a što može dovesti i do potpunog prestanka obveze osiguratelja prema osiguraniku. Niti osiguranje od odgovornosti revizora nije od toga iznimka. Štoviše, uvjetima osiguranja pojedinih osiguratelja izričito je predviđeno koje to specifične zaštitne mjere mora poduzimati osiguranik (naravno o

69 Ćurković, M., op. cit., str. 98-99. 
svom trošku, no njihovo poduzimanje može rezultirati i nižom premijom), ako ne želi da mu osiguratelj ne odbije ili ne smanji isplatu naknade štete ako dođe do nastupa osiguranog slučaja. Prema čl. 11. st. 11.5. toč. 1.-7. Uvjeta ERGO ovdje bi spadale sljedeće zaštitne mjere: a) edukacije, školovanje i stručno usavršavanje osoblja, b) dobivanje licence za osoblje i osiguranika, c) korištenje informatičkih sustava koji su licencirani te njihovo redovito održavanje i ažuriranje, korištenje antivirusne zaštite informatičkih sustava, d) redovito održavanje ostale informatičke i ostale potrebne opreme, e) držanje dokumentacije u urednom stanju (ona je u urednom stanju ako stručnjak iste struke može bez zastoja preuzeti posao i nastaviti s upotrebom dokumentacije), f) držanje dokumentacije u prostoru u kojem se provode mjere protiv krađe, požara, poplave, oluje i drugih prirodnih nepogoda, g) organiziranje rada i poslovnih procesa na način da se izbjegne kašnjenje u rokovima za izvršenje posla, predaju izvješća, slanja pismena i slično.

\subsection{Minimalne svote osiguranja}

Kod osiguranja od odgovornosti općenito, pa tako i kod osiguranja od odgovornosti zakonskih revizora, svota osiguranja gornja je granica osigurateljeve obveze, bez obzira na to koja je visina prouzročene štete. ${ }^{70}$ Svotom osiguranja unaprijed je određen maksimalni iznos obveze osiguratelja, budući da nije moguće unaprijed utvrditi štetu koju može pretrpjeti osiguranik, tj. revizorsko društvo. Ugovorena maksimalna svota osiguranja vrijedi za jedan osigurani slučaj te se odnosi na sve oštećene kao i na sve osiguranike $u$ tom osiguranom slučaju. ${ }^{71}$ Dakle, ako je nastupom istog osiguranog slučaja (propust ili pogreška u obavljanju revizije / pružanju revizorskih usluga) štetu pretrpjelo više oštećenika, ugovorena svota osiguranja dijeli se među njima ovisno o visini štete koju je svaki od njih pretrpio. Ako je zbog toga svota osiguranja nedostatna za naknadu cjelokupne štete, glede preostalog iznosa visine štete koja je ostala nepokrivena osiguranjem, oštećenicima preostaje da zahtijevaju naknadu od štetnika, tj. revizorskog društva. Po istom načelu, ako je istim ugovorom o osiguranju od odgovornosti pokrivena odgovornost više osiguranika, tj. revizorskih društava, ugovorena svota osiguranja ne zbraja se za svakog od njih, već svi oni dijele istu svotu osiguranja.

Minimalna svota osiguranja je ona koja je propisana zakonom (u ovom slučaju čl. 61. st. 1. i 2. ZRev), niže od koje se ne može ugovoriti svota osiguranja. Dopušteno je svakako ugovoriti svotu osiguranja u višem iznosu od minimalno propisane svote. Pri propisivanju minimalnih svota osiguranja Zakon o reviziji razlikuje vrstu obavljanja revizijske djelatnosti kao i subjekte nad kojima se provodi revizija. Tako, u čl. 61. st. 1 ZRev propisuje da minimalna svota pokrića po štetnom događaju (osiguranom slučaju) iznosi 300.000,00 kuna za štetu koju bi revizorsko društvo moglo prouzročiti obavljanjem revizorskih usluga. No, za štetu koju bi revizorsko društvo moglo prouzročiti obavljanjem zakonske revizije u subjektu od javnog

70 Pavić, D., Ugovorno pravo osiguranja - komentar zakonskih odredaba, Tectus, Zagreb, 2009., str. 323.

71 Ćurković, M., op. cit., str. 114. 
interesa $^{72}$ minimalna svota osiguranja po jednom štetnom događaju (osiguranom slučaju) iznosi 3.000.000,00 kuna (čl. 61. st. 2 ZRev). Dakle, ako revizorsko društvo kao osiguranik obavlja zakonsku reviziju (čl. 4. toč. 4. ZRev) subjekata od javnog interesa, minimalna svota osiguranja je znatno viša. S druge strane, ako revizorsko društvo osiguranik obavlja revizorske usluge (čl. 4. toč. 1. ZRev) pri čemu ne obavlja zakonsku reviziju subjekata od javnog interesa, minimalna svota osiguranja je znatno niža.

S obzirom na činjenicu da se osigurateljsko pokriće ugovara za osigurateljnu godinu, a za koju se plaća i premija osiguranja te da obveza osiguratelja na naknadu štete do visine ugovorene svote osiguranja (tj. minimalne propisane svote osiguranja) postoji uvijek kada nastupi novi osigurani slučaj, moguće je da ukupna obveza osiguratelja bude znatno viša, ovisno o tomu koliko je nastupilo osiguranih slučajeva iz istog ugovora o osiguranju od odgovornosti revizora. Da bi se izbjegla takva, za osiguratelja nelagodna situacija, u uvjetima osiguranja često je predviđena, tzv. agregatna osigurana svota, odnosno agregatni limit (čl. 5. st. 2 Uvjeti HUO, čl. 9. st. 9.2. Uvjeta ERGO). To je gornja granica obveze osiguratelja za sve osigurane slučajeve unutar jedne osigurateljne godine. ${ }^{73}$ Ako se u tom razdoblju dogodi više osiguranih slučaja iz istog ugovora o osiguranju od odgovornosti revizora, ukupna obveza osiguratelja iz istog ugovora o osiguranju ne može biti viša od iznosa ugovorenog agregatnog limita. Bitno je pritom naglasiti da visina agregatnog limita mora biti znatno viša, odnosno da ne bude blizu ili čak jednaka osiguranoj svoti po jednom osiguranom slučaju jer bi to onda bilo znatno ograničenje u osiguranju od odgovornosti. Naime, u tom slučaju osiguranikova odgovornost de facto ne bi bila pokrivena za novonastale osigurane slučajeve $u$ istoj osigurateljnoj godini.

\section{ZAKLJUČAK}

Zakon o reviziji iz 2017. godine ne sadrži posebne odredbe o odgovornosti za štetu zakonskog revizora prema subjektu revizije i prema trećim osobama. Stoga se na to pitanje primjenjuju opće odredbe o odgovornosti za štetu iz Zakona o obveznim odnosima. Zakonsku reviziju mogu obavljati samo revizorska društva, a ne i samostalni revizori. ZRev propisuje obvezu revizorskog društva sklopiti ugovor o osiguranju od odgovornosti za štetu koja može nastati subjektu revizije i trećim osobama pri obavljanju revizorskih usluga te propisuje najmanju svotu pokrića. Njegove su odredbe relevantne i za određenje obveza koje revizorsko društvo ima pri pružanju usluga subjektu revizije.

U ulozi štetnika pojavljuje se revizorsko društvo, a ono odgovara i za rad glavnoga revizijskog partnera, ovlaštenih revizora te drugih osoba koje nisu ovlašteni revizori, a koji su sudjelovali u obavljanju zakonske revizije u subjektu revizije u ime revizorskog društva. Budući da su oni radnici u revizorskom društvu, za njihov rad odgovara društvo.

72 Subjekt od javnog interesa je subjekt koji je kao takav određen zakonom kojim se uređuje računovodstvo poduzetnika (čl. 4. toč. 21. ZRev) (vidi o tomu više: supra 2, bilješka br. 11).

73 Ibid., str. 115. 
Odgovornost za štetu revizorskog društva prema subjektu revizije počiva na povredi ugovornih obveza iz sklopljenog ugovora o reviziji (ugovorna odgovornost za štetu), a odgovornost prema trećim osobama izvan subjekta revizije je izvanugovorna. U ime subjekta revizije zahtjev za naknadu štete prema revizorskom društvu podnose njegovi zastupnici po zakonu, a taj zahtjev ne mogu u ime subjekta koji je društvo kapitala podnijeti njegovi dioničari, odnosno članovi, budući da ga oni nisu ovlašteni zastupati. Revizorsko društvo odgovara po kriteriju predmnijevane krivnje (obična nepažnja), a namjeru i krajnju nepažnju mora dokazati subjekt revizije. On mora dokazati štetnu radnju, koja mora biti rezultat protupravnog postupanja revizorskog društva pri pružanju revizorskih usluga, nastalu štetu te uzročnu vezu između štete i štetne radnje.

Pod istim pretpostavkama zahtjev za naknadu štete prema revizorskom društvu mogu podnijeti i treće osobe koje se pojavljuju kao korisnici izvješća o reviziji, a nalaze se izvan subjekta revizije. Oni su u nepovoljnijem položaju u pogledu dokazivanja uzročne veze između nastale štete i štetne radnje revizorskog društva. Potrebno je stoga dokazati vezu između financijskog stanja u subjektu revizije i pogrešnog mišljenja koje je revizorsko društvo iskazalo u izvješću o reviziji te vezu između pogrešnog mišljenja i radnje koji je oštećenik poduzeo ili propustio poduzeti, zbog čega mu je nastala šteta. Ako treće osobe dokažu da je revizorsko društvo sudjelovalo u pogrešnom prikazivanju financijskog stanja u subjektu revizije (prijevara) moći će ostvariti naknadu štete od revizorskog društva. U drugim je slučajevima mogućnost ostvarivanja naknade štete od revizorskog društva vrlo mala.

Zahtjev oštećenika za naknadu štete u slučaju ugovorne odgovornosti zastarijeva u roku od tri godine od kada je šteta nastala, a kod izvanugovorne odgovornosti zastarijeva u roku od tri godine od kada je oštećenik doznao za štetu i osobu koja je štetnik (subjektivni rok), odnosno u svakom slučaju u roku od pet godina od kada je šteta nastala (objektivni rok). Odredbe ZOO-a o zastari su prisilne naravi.

ZRev ne propisuje ograničenje iznosa do kojega revizorska društva odgovaraju za štetu počinjenu subjektima revizije i trećim osobama. Stoga bi bilo korisno da se to propiše zakonom, sukladno Preporuci Europske komisije iz 2008. godine. To bi se ograničenje odgovornosti primjenjivalo u odnosu na štetu nastalu subjektima revizije i trećim osobama, osim ako je šteta nastala prijevarom ili namjernim postupanjem revizorskog društva pri pružanju revizorskih usluga. U slučaju ugovorne odgovornosti revizorskog društva za štetu ona se može ograničiti ugovorom o reviziji sukladno odredbama ZOO-a. Te se odredbe ne primjenjuju kada se radi o izvanugovornoj odgovornosti revizorskog društva prema trećim osobama izvan subjekta revizije.

Zbog velike važnosti koju ima djelatnost revizije za subjekte revizije, korisnike revizije, ali i kao djelatnost od javnog interesa, Zakonom o reviziji propisano je obvezno ugovaranje osiguranja od odgovornosti revizorskih društava kao preduvjet odobrenja za njihov rad. Osiguranje od odgovornosti pokriva i ugovornu i izvanugovornu odgovornost revizora. Ono, naravno, ne pokriva odgovornost za prekršajne novčane kazne izrečene revizorskom društvu, odnosno ovlaštenim revizorima. Za razliku od građanskopravne odgovornosti revizora koja načelno može biti neograničena, odgovornost osiguratelja od odgovornosti ograničena je do visine zakonom 
propisanih minimalnih svota osiguranja. S obzirom na izloženost rizicima svako revizorsko društvo može odlučiti je li potrebno ugovoriti svote osiguranja i u višem iznosu od minimalno propisanih (što povlači za sobom i plaćanje višeg iznosa premije osiguranja). Ne treba zanemariti i činjenicu da se u Republici Hrvatskoj priznaje kao jednakovrijedno osiguranje od odgovornosti koje je sklopljeno u drugoj državi članici EU-a, što može biti korisno revizorskim društvima u potrazi za povoljnijim uvjetima osiguranja i premijom osiguranja.

\section{LITERATURA}

1. Barbić, Jakša, Pravo društava, Knjiga druga - društva kapitala, Svezak I.: dioničko društvo, Organizator, Zagreb, 2010.

2. Ćurković, Marijan, Osiguranje od izvanugovorne i ugovorne (profesionalne) odgovornosti, Inženjerski biro, Zagreb, 2015.

3. Direktiva 2014/56/EU Europskog parlamenta i Vijeća od 16. travnja 2014. o izmjeni Direktive 2006/43/EZ o zakonskim revizijama godišnjih financijskih izvještaja i konsolidiranih financijskih izvještaja (tekst značajan za EPG), Službeni list EU, L 158, 27. svibnja 2014., str. 196-226.

4. European Commission, A study on systems of civil liability of statutory auditors in the context of a Single Market for auditing services in the European Union, 15 January 2001, dostupno na: http://europa.eu.int/comm/internal_market/en/company/audit/docs/ auditliability.pdf, 31. listopada 2003.

5. European Commission, Annex I to the Commission Staff Working Paper The legal systems of civil liability of statutory auditors in the European Union, Update of the study carried out on behalf of the Commission by Thieffry \& Associates in 2001, October 2006, dostupno na: http://ec.europa.eu/internal_market/auditing/docs/liability/consultation annex1_en.pdf, 3. srpnja 2018.

6. European Commission, Auditing of companies' financial statements, dostupno na: https:// ec.europa.eu/info/business-economy-euro/company-reporting-and-auditing/auditingcompanies-financial-statements_en, 5. prosinca 2017.

7. European Commission, Green Paper of the Commission 1996, The Role, the Position and the Liability of the Statutory Auditors within the European Union, dostupno na: http:// europa.eu.int/comm/internal_market/en/company/audit/docs/acten.pdf, 30. listopada 2003.

8. Europska komisija, Preporuka Komisije br. 2008/473/EZ o ograničenju građanskopravne odgovornosti samostalnih revizora i revizorskih društava od 5. lipnja 2008. godine (notificirano pod dokumentarnim brojem C(2008) 2274) (tekst značajan za EGP), Službeni list EU, L 162, 21. lipnja 2008., str. 39-40.

9. Gorenc, Vilim et al., Komentar Zakona o obveznim odnosima, RRIF plus, Zagreb, 2005.

10. Jurić, Dionis, Uloga revizora u dioničkom društvu, Zbornik Pravnog fakulteta Sveučilišta u Rijeci, vol. 25, br. 1, 2004., str. 323-352.

11. Jurić, Dionis, Neovisnost zakonskog revizora u odnosu na subjekte revizije prema Zakonu o reviziji iz 2017. godine, Zbornik Pravnog fakulteta Sveučilišta u Rijeci, vol. 39, br. 1, 2018., str. 127-156.

12. Mićović, Miodrag, Bukovac Puvača, Maja, Odgovornost za štetu prouzročenu trećim osobama obavljanjem zakonske revizije, Zbornik Pravnog fakulteta Sveučilišta u Rijeci, vol. 39, br. 1, 2018., str. 157-182.

13. Opći uvjeti za osiguranje od odgovornosti revizora ERGO osiguranje d.d. od 25. svibnja 2018. godine.

14. Pavić, Drago, Ugovorno pravo osiguranja - komentar zakonskih odredaba, Tectus, 
Zagreb, 2009.

15. Republika Hrvatska, Konačni prijedlog Zakona o reviziji, P.Z.E. br. 172, 22. studenog 2017.

16. Republika Slovenija, Zakon o spremembah in dopolnitvah Zakona o revidiranju, EVA20161611-0002, dostupno na http://www.pisrs.si/Pis.web/pregledPredpisa?id=ZAKO7354, 18. prosinca 2017.

17. Uredba (EU) br. 537/2014 Europskog parlamenta i Vijeća od 16. travnja 2014. o posebnim zahtjevima u svezi sa zakonskom revizijom subjekata od javnog interesa i stavljanju izvan snage Odluke Komisije 2005/909/EZ (tekst značajan za EGP), Službeni list EU, L 158, 27. svibnja 2014., str. 77.-112.

18. Uvjeti za osiguranje od odgovornosti osoba ovlaštenih za pružanje usluga revizije Hrvatskog ureda za osiguranje od 27. siječnja 2011. godine.

19. Zakon o obveznim odnosima, Narodne novine, br. 35/05, 41/08, 125/11, 78/15, 29/18.

20. Zakon o računovodstvu, Narodne novine, br. 78/15, 134/15, 120/16.

21. Zakon o reviziji, Narodne novine, br. 127/17.

22. Zakon o trgovačkim društvima, Narodne novine, br. 111/93, 34/99, 121/99, 52/00, 118/03, 107/07, 146/08, 137/09, 125/11, 152/11, 111/12, 68/13, 110/15. 


\author{
Dionis Jurić* \\ Loris Belanić**
}

\author{
Summary
}

\title{
CIVIL LIABILITY OF STATUTORY AUDITOR AND MANDATORY INSURANCE OF ITS CIVIL LIABILITY
}

Civil liability of statutory auditors toward audited entities and third parties is not harmonized by EU directives. It is regulated by national provisions of Member States (general provisions, special provisions or combined application of these provisions). Croatian Audit Act from 2017 does not contain special provisions on civil liability of statutary auditors. This topic is regulated by general provisions on civil liability of the Civil Obligations Act. The Audit Act envisages mandatory insurance of statutory auditors' civil liability toward audited entities and third parties and sets the minimum amount of coverage. It also sets general requirements for statutory audits in all audited entities and special requirements for statutory audits in public interest entities. Aim of these provisions is strengthening of independence and objectivity of statutory auditors towards audited entities.

Keywords: statutory auditor; civil liability; insurance; audited entities; third parties.

\section{Zussamenfassung}

\section{HAFTUNG DES ABSCHLUSSPRÜFERS UND DIE HAFTPFLICHTVERSICHERUNG}

Die Haftung des Abschlussprüfers für den an geprüfte Unternehmen und Dritte verursachten Schaden bei der Ausübung von Jahresabschlussleistungen stellt eine der offenen Fragen, welche an die einschlägigen Richtlinien der Europäischen Union nicht angepasst ist. Die Frage ist durch nationale Vorschriften der EU-Mitgliedstaaten, welche auf die Anwendung von allgemeinen oder besonderen Bestimmungen über Schadenshaftung oder auf kombinierte Anwendung genannter Bestimmungen hinweisen, reguliert. Das Gesetz über Jahresabschlüsse aus 2017 beinhaltet keine besonderen Bestimmungen über die Haftung des Abschlussprüfers. Es werden dabei die allgemeinen Bestimmungen über Schadenshaftung aus dem Schuldrechtsgesetzes angewendet. Das Gesetz über Jahresabschlüsse schreibt vor, dass der Abschlussprüfer

\footnotetext{
* Dionis Jurić, Ph.D., Full Professor, University of Rijeka, Faculty of Law; djuric@pravri.hr.

** Loris Belanić, Ph.D., Associated Professor, University of Rijeka, Faculty of Law; lorisb@ pravri.hr.
} 
bezüglich des eventuellen an geprüfte Unternehmen und Dritte verursachten Schaden dazu verpflichtet ist, die Haftpflichtversicherung abzuschließen. Ebenfalls wird die minimale Deckungssumme der Haftpflichtversicherung im Gesetz vorgeschrieben. Allgemeine Forderungen für die Durchführung von Jahresabschlüssen in allen zum Jahresabschluss pflichtigen Unternehmen sowie auch besondere Forderungen, welche an die in Subjekten von öffentlichem Interesse durchgeführten Jahresabschlüsse angewendet werden, werden auch im Gesetz bestimmt. Das Ziel dieser Bestimmungen ist es, die Unabhängigkeit und die Objektivität von Abschlussprüfern in Bezug auf die geprüften Unternehmen zu erhöhen. Ebenfalls versucht man auf diese Weise abzusichern, dass die Abschlussprüfer richtig und im Einklang mit dem Gesetz arbeiten.

Schlüsselwörter: Abschlussprüfer; Schadenshaftung; Haftpflichtversicherung, geprüfte Unternehmen; Dritte.

Riassunto

\section{LA RESPONSABILITÀ PER DANNI DEL REVISORE LEGALE E L'OBBLIGO ASSICURATIVO PER DANNI}

La responsabilità per illecito del revisore legale per il danno cagionato al soggetto della revisione ed ai terzi in occasione dell'espletamento dei servizi di revisione rappresenta una delle questioni aperte che non trova soluzioni armonizzate nelle relative direttive dell'Unione europea. L'illecito viene disciplinato dalla legislazione nazionale dei singoli Stati membri dell'UE che indirizzano all'applicazione di disposizioni generali o speciali riguardanti i danni oppure all'applicazione combinata di tali disposizioni. La legge sulla revisione del 2017 non contiene disposizioni particolari in materia di illecito dei revisori legali; bensì si applicano le disposizioni generali sulla responsabilità per danni dettata dalla Legge sui rapporti obbligatori. La Legge sulla revisione prevede l'obbligo a carico del revisore legale di concludere un contratto di assicurazione per i danni che potrebbero sorgere in capo al soggetto della revisione ed ai terzi e dispone l'importo minimo di copertura. Introduce altresì pretese generali per l'espletamento delle revisioni legali con riguardo a tutti i soggetti sottoposti ad obbligo di revisione legale e pretese specifiche che si applicano nel caso di revisioni legali di soggetti di interesse pubblico. Lo scopo di tali disposizioni è quello di rafforzare l'autonomia e l'obbiettività dei revisori legali rispetto ai soggetto della revisione e di garantire l'espletamento regolare e conforme alla legge del loro operato.

Parole chiave: revisore legale; responsabilità per danni; assicurazione per danni; soggetto della revisione; soggetti terzi. 
